\title{
Novel mechanism for lung cyst formation
}

\author{
Fasihul Khan, ${ }^{1}$ Raja Vongala Reddy ${ }^{2}$
}

${ }^{1}$ Department of Respiratory, Kettering General Hospital, Leicester, UK

${ }^{2}$ Kettering Hospital, Kettering, UK

\section{Correspondence to} Dr Fasihul Khan, fasi_k@hotmail.com

Accepted 11 December 2015

CrossMark

To cite: Khan F, Reddy RV. BMJ Case Rep Published online: [please include Day Month Year] doi:10.1136/ bcr-2015-213671

\section{DESCRIPTION}

A 75 -year-old man with a history of severe chronic obstructive pulmonary disease presented with severe cough and breathlessness, after choking on his dinner. He had a Medical Research Council grade 4 and had stopped smoking over 40 years prior. While in hospital, he coughed up a pea and was discharged home. The following day he re-presented after developing worsening dyspnoea and haemoptysis following another bout of coughing. Chest X-ray demonstrated a left apical pneumothorax, for which a chest drain was inserted. Bronchoscopy revealed inflamed haemorrhagic mucosa, with no foreign body visualised. CT of the chest demonstrated a substantial fluid-filled oval cyst with surrounding pneumothorax (figure 1). Interestingly, this was not present on the thoracic CT he had had 18 months previously, in 2014 (figure 2), and appears to have developed in an

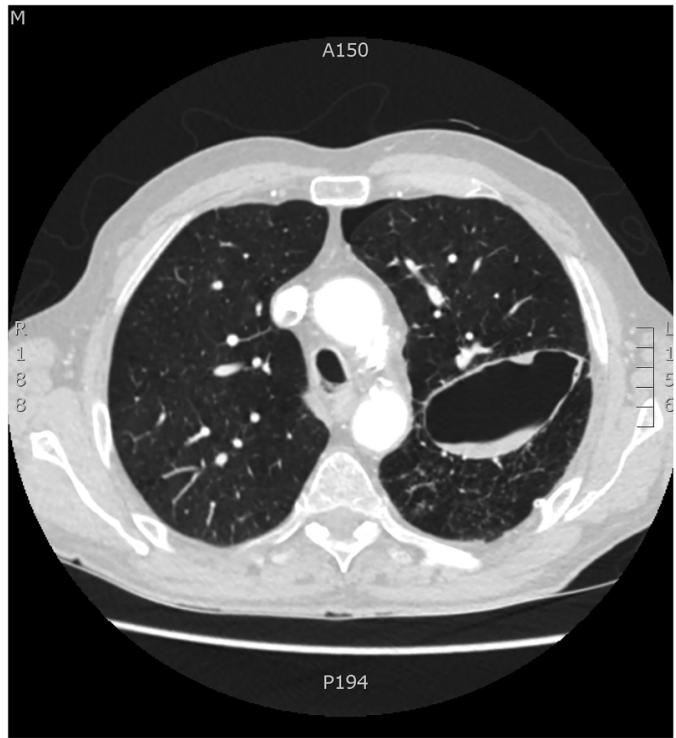

Figure 1 Fluid-filled lung cyst formation with surrounding pneumothorax (August 2015).

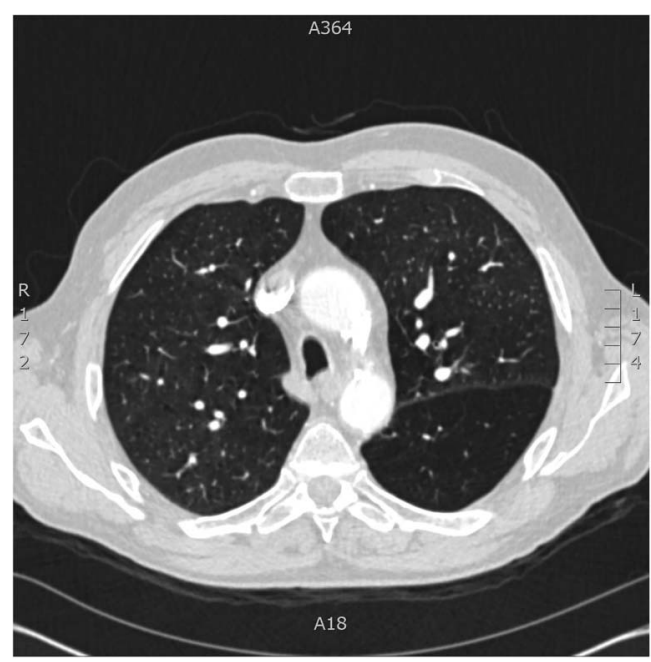

Figure 2 CT of the thorax in January 2014, with no evidence of lung cyst.

area of panlobular emphysema. This led us to believe that coughing-induced barotrauma had caused rupture of the interlobular septa, leading to haemoptysis and acute cyst formation with haemorrhage and pneumothorax.

A literature review was unable to produce other published cases of coughing-induced lung cyst formation.

\section{Learning points}

- Coughing can lead to lung cyst formation.

- Aspiration and choking can cause pneumothoraces.

Competing interests None declared.

Patient consent Obtained.

Provenance and peer review Not commissioned; externally pee reviewed.

Copyright 2016 BMJ Publishing Group. All rights reserved. For permission to reuse any of this content visit http://group.bmj.com/group/rights-licensing/permissions.

BMJ Case Report Fellows may re-use this article for personal use and teaching without any further permission.

Become a Fellow of BMJ Case Reports today and you can:

- Submit as many cases as you like

- Enjoy fast sympathetic peer review and rapid publication of accepted articles

- Access all the published articles

- Re-use any of the published material for personal use and teaching without further permission

For information on Institutional Fellowships contact consortiasales@bmjgroup.com

Visit casereports.bmj.com for more articles like this and to become a Fellow 